\title{
Differential equations with modified argument, via weakly Picard operators' theory
}

\section{VIORICA MUREŞAN}

\begin{abstract}
.
In this paper we use Picard and weakly Picard operators technique, introduced by Ioan A. Rus, to study a class of differential equations with modified argument and a boundary value problem for this kind of equations. We obtain existence, uniqueness, comparison and data dependence results.
\end{abstract}

Department of MATHEMATics

TECHNICAL UNIVERSITY OF CLUJ-NAPOCA,

FACULTY OF AUTOMATION AND COMPUTER SCIENCES,

Memorandumului 28, 400114 Cluj-NAPOCA, Romania

E-mail address: vmuresan@math.utcluj.ro

Received: 30.10.2011; In revised form: 03.09.2012; Accepted: 15.10.2012

2010 Mathematics Subject Classification. 34K05, 34K15, 47H10.

Key words and phrases. Fixed point, boundary values problem, data dependence, comparison result. 